\title{
Factors Affecting Choice Of Health Care Facilities Among The Adults of an Urban Community
}

Raksha Shrestha ${ }^{1}$ and Sarita Adhikari ${ }^{2}$

${ }^{1}$ Tribhuvan University Teaching Hospital, Maharajgunj, Kathmandu, Nepal

${ }^{2}$ College of Nursing, Nepalese Army Institute of Health Sciences, Sanobharyang, Kathmandu, Nepal

\begin{abstract}
Introduction: Health service delivery systems that are safe, accessible, high quality, people-centred, and integrated are critical for moving towards universal health coverage. World Health Organisation is supporting to improve the efficiency and effectiveness of health service delivery systems to all the population not only the patients. This study aims to identify the factors affecting the choice of health care facilities among the adults of an urban community and its association with the selected sociodemographic variables.

Methods: A descriptive cross-sectional study was conducted among the community residence with 120 respondents using non-probability purposive sampling technique. Data was collected using semistructured interview schedule that was analysed by using descriptive statistical methods such as frequency, percentage, mean, standard deviation and inferential statistics such as chi-square test.

Result: The findings of the study revealed that majority $(60.8 \%)$ of the respondents used private health care facilities and there was significant association of the choice of health care facility with the health care services related factors whereas no significant association was found with the selected sociodemographic variables.

Conclusions: Based on the study findings, it concluded that various health care services related factors like availability, affordability, acceptability and accessibility factors tends to affect the choice of health care facility.

Key words: Adults; Factors; Public health care facility; Private health care facility
\end{abstract}

Correspondence: Raksha Shrestha, Tribhuvan University Teaching Hospital, Maharajgunj, Kathmandu, Nepal. Email: rakshashrestha804@gmail.com

DOI: $10.3126 / \mathrm{mjsbh.v20i2.30777}$

Submitted on: 2020-08-23

Accepted on: 2021-06-10 


\section{INTRODUCTION}

People's choices are determined by a complex interplay between a variety of patient and provider characteristics. In various Northwest European countries, there is a demand-driven health care system that stresses the importance of patient health care provider choice. In most European countries, patients are encouraged to actively choose their health care provider. Important reasons for promoting patient choice are to reduce waiting times and to encourage competition between providers. ${ }^{1}$

On the other hand, health care system in Nigeria has a mixture of private and public health care providers. ${ }^{2}$ Unlike in many other developed nations, health care in Nigeria is not universally free. Choice of health care providing facility is an important decision for the patient seeking the best health care for oneself. This decision-making process is determined by factors external to the clients such as cost, accessibility as well as quality of services provided by the health care facilities. Satisfaction of services provided is a perception by the clients and must be considered by managers of health institutions when decisions to improve health facility services are to be made. ${ }^{2}$

Nepal is a developing nation with sub optimal health care services. Although the health care system in the country has been progressive, it is still far from perfection. According to Department of Health Survey (DOHS), Nepal, 533 hospitals were listed in the Health Management Information System under Department of Health Services in 2015/16, of which 118 (22\%) were public hospitals and 415 (78\%) non-public hospitals. Annual health report of 2015/16 claims more than $50 \%$ of the people of Nepal have used public health services in 2015/16. Eighty-one percentage of registered morbidity cases used free health care services and $91 \%$ of the population who used free health care services did so at health post, $5 \%$ at hospitals and $4 \%$ at Primary Health Care Centres. ${ }^{3}$

Nepal, being a developing nation, has to put in lot of efforts to improve in all the basic components of various sectors like health care, education, agriculture, transportation, industries etc. Though various measures are being launched in various parts of the nation, there is still lack of sufficient knowledge, accessibility, health supply and resources for the optimum level of developmental activities. Health care sector is one of those challenging sectors. Regarding the choice of health care, there are so many factors that could determine for their approach that could be accessibility wise, economic wise or resources wise. Therefore, this study was conducted to identify the factors affecting the choice of health care facilities either public or private and its association with the selected variables and clarify the tangentiality.

\section{METHODS}

A descriptive cross-sectional study design was used to identify the factors (health care services related factors like availability, affordability, acceptability and accessibility) affecting the choice of health care facilities among the adults aged from 20 to 59 years. The study subjects were chosen from each household who had received health care services in recent one year of time, residing in Kageshwori Manohara Municipality, Kathmandu, Nepal. Data was collected for around two weeks through semistructured interview between 05 Jun 2019 and 22 Jun 2019. The study was initiated after getting approval from ward office of Kageshwori Manohara Municipality, Mulpani ward no.7. The statements were prepared in English and converted to local Nepali language for easy understanding. Interview schedule was divided into three parts: Part I related to socio-demographic information of the respondents. Part II related to use of health care facilities. Part III included the statements related to various factors affecting the choice of health care facility. The instrument was pre-tested on $10 \%$ of the total sample size i.e. twelve samples in the same community residents which were later excluded from the study, for correct understanding of the instrument and the necessary modification was done. Ethical approval was taken from Institutional Review Committee of Nepalese Army Institute of Health Sciences, Sanobharyang, Nepal. An informed written consent was obtained from each participant prior to data collection by explaining the purpose of the study. Confidentiality of the information was ensured by maintaining privacy while interviewing. Data analysis was done via statistical package for the social sciences (SPSS) version 20 programs through descriptive and inferential statistics. Chi-square test was used to 
find out the association of different variables to the choice of health care facilities considering $p$ value of $<0.05$ as significant association.

\section{RESULT}

Total 120 adults participated in the study. The sample showed that about one third $(32.5 \%)$ of the respondents belonged to the age group $20-29$ years and $10.8 \%$ of the respondents were in the range of 50 - 59 years with the mean age 35.7 years and standard deviation \pm 9.9 where $59.2 \%$ of respondents were males. Majority $(70.8 \%)$ of the respondents were married. Majority (70.8\%) were from Brahmin / Chhetri ethnicities. Almost all (98.3\%) of respondents could read and write, out of which $40.6 \%$ had their education up to secondary level and $37.5 \%$ were involved in business as their main occupation. Majority (69.2\%) of the respondent belonged to nuclear family. Most of them $(75.8 \%)$ had enough income for daily livelihood.

Majority (60.8\%) of the respondents had used private health care facility within one year duration. Most (75.8\%) of respondents had sought medical service for common medical conditions like fever, hypertension, chronic obstructive pulmonary disease etc. Minor proportion (4.2\%) had visited health facilities for other conditions accounting like joint pain $(1.7 \%)$, skin problem $(1.7 \%)$ and paediatric illnesses $(0.8 \%)$. Among all the medical attention seekers, 19.2\% got admitted for their illness, out of which $15.8 \%$ had stayed for $\leq$ eight days in the health care facility.

We found out that the main selected availability related factors were less waiting time $(74.0 \%)$, clean and tidy environment (89.0\%), well equipped $(98.6 \%)$ among the people who chose private health care facilities and good reputation (83.0\%) was the major factor which led to the choice among those who public health facility. This factor has the significant association with choice of health care facilities with $p$-value $<0.05$.

Among the choices, our results showed that selected affordability related factors as cost of treatment $(87.2 \%)$, freely available medicines (40.4\%) and consultation (38.3\%) are the major causes in their choice of public health care facility. This has significant association with the choice of health care facility with the p-value being $<0.05$. The selected acceptability related factors mentioned as timely response $(84.9 \%)$, good explanation $(83.6 \%)$, medical personnel answering the queries and confidentiality of words $(90.4 \%)$ who chose private health facility, has significant association with the choice of health care facility with $p$-value

Table 1. Socio-demographic Characteristics of the Respondents $(\mathrm{N}=120)$

\begin{tabular}{|c|c|c|}
\hline Variables & Frequency & Percentage \\
\hline \multicolumn{3}{|l|}{$\begin{array}{l}\text { Mean age }=35.7 \text { years and } \\
\mathrm{SD}= \pm 9.9\end{array}$} \\
\hline \multicolumn{3}{|l|}{ Sex } \\
\hline Male & 71 & 59.2 \\
\hline Female & 49 & 40.8 \\
\hline \multicolumn{3}{|l|}{ Marital status } \\
\hline Married & 85 & 70.8 \\
\hline Unmarried & 34 & 28.3 \\
\hline Widowed / Widower & 1 & 0.8 \\
\hline \multicolumn{3}{|l|}{ Ethnicity } \\
\hline Brahmin / Chhetri & 85 & 70.8 \\
\hline Janajati & 28 & 23.3 \\
\hline $\begin{array}{l}\text { Others (Dalit and } \\
\text { Madhesi) }\end{array}$ & 7 & 5.9 \\
\hline \multicolumn{3}{|l|}{ Educational status } \\
\hline Can read and write & 118 & 98.3 \\
\hline Can't read and write & 2 & 1.7 \\
\hline \multicolumn{3}{|l|}{$\begin{array}{l}\text { If can read and write }(n= \\
118)\end{array}$} \\
\hline Primary level & 25 & 21.8 \\
\hline Secondary level & 48 & 40.6 \\
\hline $\begin{array}{l}\text { Bachelor's level and } \\
\text { above }\end{array}$ & 45 & 38.1 \\
\hline \multicolumn{3}{|l|}{ Occupation } \\
\hline Business & 45 & 37.5 \\
\hline Service & 33 & 27.5 \\
\hline Farmer & 20 & 16.7 \\
\hline Home-maker & 10 & 8.3 \\
\hline $\begin{array}{l}\text { Others (Abroad and } \\
\text { labour) }\end{array}$ & 12 & 10.0 \\
\hline \multicolumn{3}{|l|}{ Family Type } \\
\hline Nuclear family & 83 & 69.2 \\
\hline Joint family & 37 & 30.8 \\
\hline \multicolumn{3}{|l|}{$\begin{array}{l}\text { Family Income } \\
\text { (Participant's own word) }\end{array}$} \\
\hline $\begin{array}{l}\text { Enough for daily } \\
\text { livelihood }\end{array}$ & 91 & 75.8 \\
\hline $\begin{array}{l}\text { More than enough } \\
\text { daily livelihood }\end{array}$ & 23 & 19.2 \\
\hline $\begin{array}{l}\text { Not enough for daily } \\
\text { livelihood }\end{array}$ & 6 & 5.0 \\
\hline
\end{tabular}


Table 2. Health Care Facilities related Information of the Respondents $(\mathrm{N}=120)$

\begin{tabular}{|c|c|c|}
\hline Variables & Frequency & $\%$ \\
\hline \multicolumn{3}{|l|}{$\begin{array}{l}\text { Used health care facility within } \\
\text { the one year duration }\end{array}$} \\
\hline $\begin{array}{l}\text { Private health care } \\
\text { facilities }\end{array}$ & 73 & 60.8 \\
\hline $\begin{array}{l}\text { Public health care } \\
\text { facilities }\end{array}$ & 47 & 39.2 \\
\hline \multicolumn{3}{|l|}{ Purpose of the visit } \\
\hline Medical condition & 91 & 75.8 \\
\hline Surgical condition & 12 & 10.0 \\
\hline Gynecology problems & 12 & 10.0 \\
\hline $\begin{array}{l}\text { Others (joint pain, skin } \\
\text { problem, pediatric } \\
\text { problems) }\end{array}$ & 5 & 4.2 \\
\hline \multicolumn{3}{|l|}{$\begin{array}{l}\text { Admitted to any health care } \\
\text { facility }\end{array}$} \\
\hline Yes & 23 & 19.2 \\
\hline No & 97 & 80.8 \\
\hline \multicolumn{3}{|l|}{ Duration of admission $(n=23)$} \\
\hline$\leq 8$ days & 19 & 15.8 \\
\hline$>8$ days & 4 & 3.3 \\
\hline
\end{tabular}

$<0.05$. This association clarifies that the emotional health is as important as one's physical health.

The selected accessibility related factors like easy availability of transportation $(80.8 \%)$ and low travel time $(74.0 \%)$ were important while choosing private health care. This has significant association with the choice of health care facilities with $p$-value $<0.05$. This is because of the universal fact that the duration of distance and means of transportation is of great importance as waste of time is waste of money.

We did not find any significant association of socio-demographic variables with the choice of health care facilities. This is explained by the fact that Kathmandu's literacy rate is increasing day by day (it was $89.6 \%$ according to 2011 census) and everyone is taking the health factor as the prime thing. Hence, there is no socio-demographic background which could affect the choice of health care facility. Rather, this choice is entirely dependent upon the quality of services that the health care facilities provide to the people.

\section{DISCUSSION}

The present study revealed that majority $(60.8 \%)$ of respondents has used private health care facility out
Table 3. Association of Availability Related factor with the Choice of Health Care Facility

\begin{tabular}{|c|c|c|c|c|}
\hline \multirow[t]{2}{*}{ Variables } & \multicolumn{2}{|c|}{$\begin{array}{l}\text { Choice of Health } \\
\text { Care Facility }\end{array}$} & \multirow{2}{*}{$\begin{array}{l}\text { Chi- } \\
\text { square } \\
\text { value }\end{array}$} & \multirow[t]{2}{*}{$\begin{array}{c}\text { p- } \\
\text { value }\end{array}$} \\
\hline & $\begin{array}{l}\text { Private } \\
\text { health } \\
\text { care } \\
\left(\begin{array}{c}\mathrm{N}=73) \\
\text { f } \%\end{array}\right.\end{array}$ & $\begin{array}{l}\text { Public } \\
\text { health } \\
\text { care } \\
\left(\begin{array}{c}N=47) \\
\text { f } \%\end{array}\right.\end{array}$ & & \\
\hline \multirow{2}{*}{$\begin{array}{c}\text { Less waiting } \\
\text { time for } \\
\text { consultation } \\
\text { Yes }\end{array}$} & & & & \\
\hline & $\begin{array}{r}54 \\
(74.0 \%)\end{array}$ & $\begin{array}{r}9 \\
(19.1 \%)\end{array}$ & 34.461 & 0.000 \\
\hline No & $\begin{array}{r}19 \\
(26.0 \%)\end{array}$ & $\begin{array}{r}38 \\
(80.9 \%)\end{array}$ & & \\
\hline $\begin{array}{l}\text { Clean and tidy } \\
\text { environment } \\
\text { of the health } \\
\text { care facility }\end{array}$ & & & & \\
\hline Yes & $\begin{array}{r}65 \\
(89.0 \%)\end{array}$ & $\begin{array}{r}27 \\
(57.4 \%)\end{array}$ & 15.954 & 0.000 \\
\hline No & $8(11.0 \%)$ & $\begin{array}{r}20 \\
(42.6 \%)\end{array}$ & & \\
\hline $\begin{array}{l}\text { Well equipped } \\
\text { health care } \\
\text { facilities with } \\
\text { the needed } \\
\text { facilities and } \\
\text { services* }\end{array}$ & & & & \\
\hline Yes & $\begin{array}{r}72 \\
(98.6 \%)\end{array}$ & $\begin{array}{r}42 \\
(89.4 \%)\end{array}$ & 5.171 & 0.034 \\
\hline No & $1(1.4 \%)$ & $\begin{array}{r}5 \\
(10.6 \%)\end{array}$ & & \\
\hline $\begin{array}{l}\text { Good } \\
\text { reputation of } \\
\text { doctors and } \\
\text { the health care } \\
\text { facility }\end{array}$ & & & & \\
\hline Yes & $\begin{array}{r}47 \\
(64.4 \%)\end{array}$ & $\begin{array}{r}39 \\
(83.0 \%)\end{array}$ & 4.869 & 0.027 \\
\hline No & $\begin{array}{r}26 \\
(35.6 \%)\end{array}$ & $\begin{array}{r}8 \\
(17.0 \%)\end{array}$ & & \\
\hline
\end{tabular}

*Fisher's Exact Test

of which $91.8 \%$ chose private health care facility as the reception staffs were easy to approach, $98.6 \%$ believed that the private facility is well-equipped and $90.4 \%$ believed that the staffs at private set up are friendly, cooperative and respectful. Our finding is consistent with a similar type of study done in Oman revealing that the selection of hospital was made when hospital staffs were friendly and helpful (68.2\%) and when the facility was equipped with modern equipment $(60.3 \%)$ and 
Table 4. Association of Affordability Related factor with the Choice of Health Care Facility

\begin{tabular}{|l|l|l|}
\hline Variables & Choice of Health & p- \\
Care Facility & Chi- & value \\
Private & Public & square \\
health & health & value \\
care & care \\
$(\mathrm{n}=73)$ & $(\mathrm{n}=47)$ \\
$\mathrm{f} \%$ & $\mathrm{f} \%$ & \\
\hline
\end{tabular}

Cost of treatment, consultation fee and medicine are within the capacity to pay

\begin{tabular}{|l|l|l|l|l|} 
Yes & 44 & 41 & 10.059 & 0.002 \\
& $(60.3 \%)$ & $(87.2 \%)$ & & \\
\hline No & 29 & 6 & & \\
\hline
\end{tabular}

Medicines are available free of cost

\begin{tabular}{l|l|l} 
Yes & 11 & 19 \\
& $(15.1 \%)$ & $(40.4 \%)$ \\
No & 62 & 28 \\
& $(84.9 \%)$ & $(59.6 \%)$
\end{tabular}

$9.805 \quad 0.002$

$$
(39.7 \%)(12.8 \%)
$$

\section{Free consultation}

\begin{tabular}{l|l|l} 
Yes & 7 & 18 \\
& $(9.6 \%)$ & $(38.3 \%)$ \\
No & 66 & 29 \\
& $(90.4 \%)$ & $(61.7 \%)$
\end{tabular}

when the doctors treated patients in a friendly manner $(65.3 \%){ }^{4}$

The present study revealed that adults preferred to visit private health care facilities $(60.8 \%)$ as compared to the public health care facility $(39.2 \%)$. They were satisfied with the less waiting time (74.0\%), clean and tidiness (89.0\%), equipment and resource $(98.6 \%)$, timely response $(84.9 \%)$ and competent doctors and nurses (93.2\%). This is in agreement with a study done among Ghanaian health seekers where $44.7 \%$ of the respondents were satisfied with the lesser wait time, better conditions and accessibility of private health facility in comparison to public health care facility. ${ }^{5}$

The present study showed that there is significant association of selected affordability related factors (Cost of treatment, freely available medicines and consultation) and selected acceptability related factors (timely response, good explanation, medical personnel answering the queries and confidentiality of words) with the choice of health care facility. This is consistent with similar study done in North-
Table 5. Association of Acceptability Related factor with the Choice of Health Care Facility

\begin{tabular}{|c|c|c|c|}
\hline Variables & $\begin{array}{c}\text { Choice of Health } \\
\text { Care }\end{array}$ & $\begin{array}{c}\text { Chi- } \\
\text { square }\end{array}$ & value \\
Private & Public & value \\
health & health \\
care & care \\
$(\mathrm{n}=73)$ & $(\mathrm{n}=47)$ \\
$\mathrm{f} \%$ & $\mathrm{f} \%$ & \\
\hline
\end{tabular}

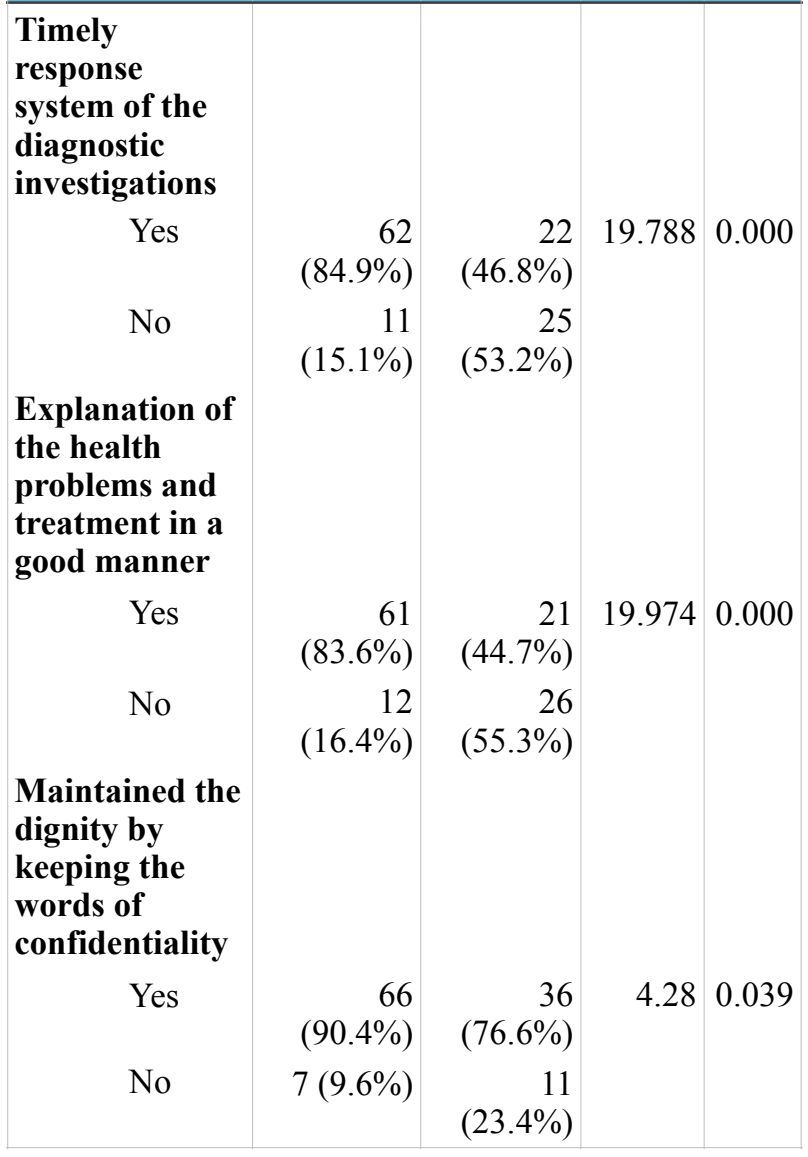

Central Nigeria which showed a statistical relationship between the health seeking preferences and the reason for choosing a particular health care service. ${ }^{6}$ Amongst the reasons provided by the respondents, the cost of medication $(42.2 \%)$, presumed skills of the staff $(21.4 \%)$ and the proximity to the health facility $(20.8 \%)$ were the most important ones. The attitude of the staff $(15.6 \%)$ constituted the least important reason for the choice. ${ }^{6}$

We found that there is a significant association of selected accessibility related factors like easy availability of transportation, lesser travel time, lesser waiting time, clean and tidy environment, well equipped and good reputation while choosing health care facilities. Similar study from Riyadh, Saudi Arabia had showed variables like location of health care facility and waiting time were 
Table 6. Association of Accessibility Related factor with the Choice of Health Care Facility

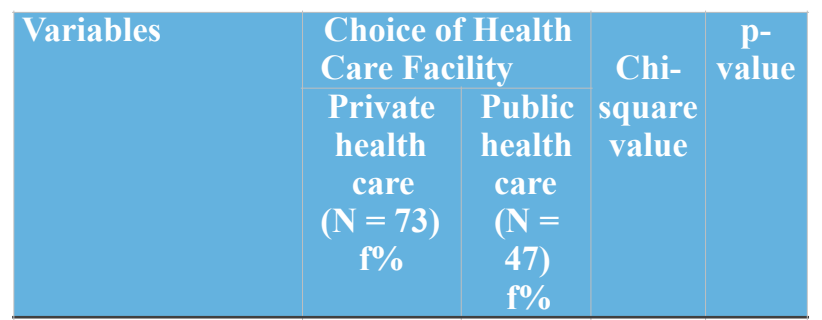

Easy availability

of transportation

Yes

$$
\begin{array}{|l|l|}
59 & 21 \\
(80.8 \%) & (44.7 \%)
\end{array}
$$

\begin{tabular}{l|l|l} 
No & 14 & 26
\end{tabular}

$(19.2 \%) \quad(55.3 \%)$

The travel time is

low to reach the

health care

facility

\begin{tabular}{|l|l|l|} 
Yes & 54 & 18 \\
& $(74.0 \%)$ & $(38.3 \%)$ \\
No & 19 & 29 \\
& $(26.0 \%)$ & $(61.7 \%)$
\end{tabular}

statistically significant in choosing the health care facility. ${ }^{7}$

\section{CONCLUSIONS}

Based on the study findings it concludes that the study population chose private health care facility over public health facility. The choice was made considering availability, affordability, acceptability and accessibility related factors of health care service. Therefore, the hospitals or any organisations involved in the health care delivery should focus on the prime aspects of efficient and effectiveness of quality of health care which should be easily available, affordable, accessible as well as acceptable.

\section{ACKNOWLEDGEMENT}

Researcher would also like to show her sincere gratitude towards Kageshwori Manohara Municipality, ward-07, ward office for granting the permission to conduct the research activity and all the respondents for their co-operation and valuable time. We are also grateful towards the Institutional Ethical Review Committee of the Nepalese Army Institute of Health Sciences for providing ethical guidelines and approving for the study.
Table 7. Association of selected Socio-demographic Variables with the Choice of Health Care Facility

$(\mathrm{N}=120)$

\begin{tabular}{l|c|c|c|}
$\begin{array}{l}\text { Socio- } \\
\text { demographic }\end{array}$ & $\begin{array}{c}\text { Choice of health } \\
\text { care facility }\end{array}$ & $\begin{array}{c}\text { Chi- } \\
\text { squa }\end{array}$ & $\begin{array}{c}\text { p- } \\
\text { value }\end{array}$ \\
variables & $\begin{array}{c}\text { Private } \\
\text { health }\end{array}$ healic & re \\
care & care & \\
& $(\mathrm{N}=73)$ & $(\mathrm{N}=47)$ & \\
\hline
\end{tabular}

Age

$20-36$

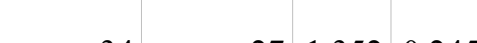

$37-59$

$\begin{array}{rr}34 & 27 \\ (46.6 \%) & (57.5 \%)\end{array}$

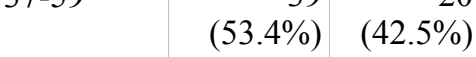

\section{Gender}

Male

43

\begin{tabular}{r|r|r}
28 & 0.005 & 0.942
\end{tabular}

Female

$(58.9 \%) \quad(59.6 \%)$

Ethnicity

$$
\begin{array}{rr}
30 & 19 \\
(41.1 \%) & (40.4 \%)
\end{array}
$$

Brahmin /

Chhetri

47

$(64.4 \%)$

Others

Marital status

Married

$(35.6 \%)$

$(80.8 \%)$

\begin{tabular}{|l|l|l|}
38 & 3.753 & 0.053
\end{tabular}

Single

Educational

status*

Can read

and write

Can't read and write

Family Type

Nuclear

family

Joint

family

Family Income

Enough for

daily

livelihood

More than

enough for

daily

livelihood

Number of

Family members

$\leq 5$
$>5$

51
$(69.9 \%)$

)

$(63.8 \%)$

$(100.0 \%) \quad(95.7 \%)$

$0(0.0 \%) \quad 2(4.3 \%)$

(19.2\%)

(71.2\%)

(70.2\%)

\begin{tabular}{|l|l|l|}
33 & 0.014 & 0.904
\end{tabular}

(28.8\%)

(29.8\%)

\section{4}

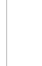


To cite this article: Shrestha R, Adhikari S. Factors Affecting Choice Of Health Care Facilities Among The Adults of an Urban Community. MJSBH. 2021;20(2):123-9.

Conflict of Interest: None declared

\section{REFERENCES}

1. Victoor A, Delnoij DM, Friele RD, Rademakers J. Determinants of patient choice of healthcare providers: a scoping review. BMC Health Serv Res. 12(272):10-186. DOI: https://doi.org/10.1186/1472-6963-12-272

2. Uchendu OC, Ilesanmi OS, Olumide AE. Factors influencing the choice of health care providing facility among workers in a local government secreteriat in South Western Nigeria. Ann Ib Post Grad Med. 2013;11(2):87-95. PMID: 25161426

3. Department of Health Survey. (2073-2074). Glimpse of annual report. Nepal: Ministry of Health and Population. Retrieved from: https://publichealthupdate.com/annual-report-of-the-department-of-health-services-dohs/

4. Al-Balushi S, Khan FR. Factors influencing the preference of private hospitals to public hospitals in Oman. IJMIER. 2017 Sep: 2395-7662. DOI: 10.18510/ijmier.2017.323

5. Tenkorang EY. Health provider characteristics and choice of health care facility among Ghanaian health seekers. Health Syst reform. 2016 Apr 2;2(2):160-70. DOI: 10.1080/23288604.2016.1171282

6. Audu O, Bako IA, Abdullahi AU, Nanben VO, Avidime S. Sociodemographic correlates of choice of health care services in six rural communities in North Central Nigeria. Adv Public Health. 2014 Dec 22;2014. DOI: https:// doi.org/10.1155/2014/651086

7. Al-Ghanim SA. Factors influencing the utilisation of public and private primary health care services in Riyadh city. JKAU Mar Sci Econ \& Adm. 2004;19(1):3-27. DOI:11.01.1426H

8. Gil MR, Choi CG. Factors affecting the choice of national and public hospitals among outpatient service users in South Korea. Inquiry. 2019 Apr; 56:0046958019833256. DOI: https://doi.org/10.1177/0046958019833256

9. Karkee R, Kadariya J. Choice of health-care facility after introduction of free essential health services in Nepal. WHO South East Asia J Public Health. 2013;2(2):96-100. DOI: 10.4103/2224-3151.122941

10. Liu Y, Kong Q, Yuan S, van de Klundert J. Factors influencing choice of health system access level in China: A systematic review. PLOS ONE. 2018 Aug 10;13(8):e0201887. DOI: https://doi.org/10.1371/journal.pone.0201887

11. Mosadeghrad AM. Patient choice of a hospital: implications for health policy and management. Int J Health Care Qual Assur. 2014 Mar 3. DOI: https://doi.org/10.1108/ijhcqa-11-2012-0119

12. Dharmesh M, Devendra S. Factors affecting patients' decision in selection of hospital. Strateg Manag J. 2014;25 (3):5-10. Retrieved from: https://ideas.repec.org/a/brc/journl/v25y2014i3p5-10.html

13. Patel PD, Singh MB. (2075). Essential textbook of nursing research and biostatistics. Kathmandu: Samiksha Publication Private Limited.

14. Tang $\mathrm{C}, \mathrm{Xu}$ J, Zhang M. The choice and preference for public-private health care among urban residents in China: evidence from a discrete choice experiment. BMC Health Serv Res. 2016 Dec;16(1):61-1. DOI: https://doi.org/ 10.1186/s12913-016-1829-0

15. Thapa AK, Adhikari SR. Characteristics of morbidity and choice of health care facilities in Nepal. J Adv Res. 2015;2(2):47-55. DOI: https://doi.org/10.3126/jaar.v2i2.16605

16. United Nation International Children's Education Fund. (2018). A vision for primary health care in the 21 st century. Kazakastan: World Health Organisation. Retrieved from: https://apps.who.int/iris/handle/10665/328065 